\title{
CCA-C RETENTION \& PENETRATION IN PINO CHUNCHO WOOD (Schizolobium amazonicum Huber. Ex Ducke) FOR NON-STRUCTURAL USE
}

\author{
Florencio T. Trujillo Cuellar ${ }^{*}$, Alex A. Aguirre Cortez², Ricardo Jorge Klitzke³, Márcio Pereira Da Rocha ${ }^{4}$, \\ Hector E. Gonzales Mora ${ }^{5}$, Martín Araujo Flores ${ }^{6}$ \\ $\mathbf{1}^{*}$ Faculty of Forestry Sciences of "La Molina” National Agrarian University - UNALM, Lima, Peru - ftrujillo@lamolina.edu.pe \\ ${ }^{2}$ Faculty of Forestry Sciences of "La Molina” National Agrarian University - UNALM, Lima, Peru - alexaguirre07@ hotmail.com \\ ${ }^{3}$ Postgraduate Program in Forestry Science at the Federal University of Paraná, Brazil - rjkklitzke@gmail.com \\ ${ }^{4}$ Postgraduate Program in Forestry Science at the Federal University of Paraná, Brazil - mprocha01@gmail.com \\ ${ }^{5}$ Faculty of Forestry Sciences of "La Molina" National Agrarian University - UNALM, Lima, Peru - egonzales@ lamolina.edu.pe \\ ${ }^{6}$ Faculty of Forestry Sciences of "La Molina” National Agrarian University - UNALM, Lima, Peru - maraujof@lamolina.edu.pe
}

Received for publication: 17/01/2020 - Accepted for publication: 03/09/2020

\begin{abstract}
Resumo
Retenção e penetração de CCA-C em madeira de pinheiro chuncho (Schizolobium amazonicum huber. ex ducke) para uso não estrutural. A qualidade do tratamento foi avaliada, através da retenção e penetração de CCA-C em madeira de pinheiro chuncho (Schizolobium amazonicum Huber. Ex Ducke), para uso não estrutural em ambientes internos $\left(4 \mathrm{~kg} / \mathrm{m}^{-3}\right)$ e externos $\left(6,4 \mathrm{~kg} / \mathrm{m}^{-3}\right)$, por imersão simples e métodos de célula cheia. Cinco árvores foram selecionadas aleatoriamente em uma plantação de 23 anos, produzindo 64 exemplares de $50 \mathrm{~mm}$ x $50 \mathrm{~mm}$ de seção transversal e $500 \mathrm{~mm}$ de comprimento com $15 \%$ de umidade. O método de imersão simples no período de 2 a 14 dias apresentou retenções médias entre 1,5 a $3,7 \mathrm{~kg} / \mathrm{m}^{-3}$, semelhantes aos resultados pelo método de célula cheia com $120 \mathrm{lb} \cdot /$ in..$^{-2}$ por 10, 20 e 30 minutos de tratamento apresentando retenções médias entre 3,2 a $3,9 \mathrm{~kg} / \mathrm{m}^{-3}$, ambos os métodos com penetrações do produto preservante do tipo vascular parcial. Com $150 \mathrm{lb} . / \mathrm{in} .^{-2}$ e 10,20 e 30 minutos de tratamento, foram observadas retenções entre 5,1 e $5,9 \mathrm{~kg} / \mathrm{m}^{-3}$, com penetrações do produto preservante do tipo parcial irregular. Finalmente, com $180 \mathrm{lb}$./in..$^{-2}$ para 10,20 e 30 minutos de tratamento, foram alcançadas penetrações e retenções regulares do produto preservante do tipo total de $5,6,7,4$ e $8,1 \mathrm{~kg} / \mathrm{m}^{-3}$, respectivamente, adequadas para uso não estrutural em ambientes internos (com 10 minutos), e em ambientes internos e externos (20 e 30 minutos). A influência do aumento da pressão no aumento da retenção no mesmo tempo de tratamento foi significativa, ao contrário do aumento do tempo na mesma pressão de tratamento.

Palavras-chave: Imersão, tratamento de preservação, método de célula cheia, qualidade do tratamento
\end{abstract}

\section{Abstract}

The quality of wood treatment, by retention and penetration of CCA-C was evaluated in pino chuncho wood (Schizolobium amazonicum Huber. Ex Ducke), for non-structural use indoors $\left(4 \mathrm{~kg} / \mathrm{m}^{-3}\right)$ and outdoors $\left(6.4 \mathrm{~kg} / \mathrm{m}^{-3}\right)$ by the simple dipping (immersion) and full-cell methods. Thus, five trees from a 23-year-old plantation were randomly selected, producing 64 samples with a cross section of $50 \mathrm{~mm}$ x $50 \mathrm{~mm}$ and $500 \mathrm{~mm}$ long with $15 \%$ moisture content. The simple immersion treatment of 2 to 14 days showed average retentions between 1.5 to $3.7 \mathrm{~kg} / \mathrm{m}^{-3}$, similar to results by the full-cell method with a pressure of $120 \mathrm{lb} . / \mathrm{in} .^{-2}$ by 10,20 and 30 minutes of treatment showing average retentions from 3.2 to $3.9 \mathrm{~kg} / \mathrm{m}^{-3}$; during both methods penetration of a partial vascular type preservative was applied. With $150 \mathrm{lb} . / \mathrm{in} .^{-2}$ and 10,20 and 30 minutes of treatment, retentions between 5.1 and $5.9 \mathrm{~kg} / \mathrm{m}^{-3}$, with irregular partial preservative penetrations were observed. Finally, with $180 \mathrm{lb} . /$ in. $^{-2}$ for 10,20 and 30 minutes of treatment, regular total preservative penetrations, and retention of $5.6,7.4$ and $8.1 \mathrm{~kg} / \mathrm{m}^{-3}$ respectively, were achieved, suitable for non-structural use indoors (with 10 minutes), and indoors and outdoors (with 20 and 30 minutes). The influence of increased pressure on increased retention with the same treatment time was significant, unlike increasing the treatment time at the same treatment pressure.

Keywords: Immersion, preservation treatment, full-cell method, treatment quality

\section{INTRODUCTION}

As part of the Carbon Sequestration Project in the Central Forest, Oxapampa-Peru, for the past 25 years efforts have been made to replenish the forest with the participation of the Reforestation Committees of Oxapampa, Villa Rica, Iscozacín, and Puerto Bermúdez, the Peruvian-German Project "Forestry and Agroforestry Development in the Central Forest," the Pichis-Palcazú Special Project, and private initiatives that have installed forest plantations of different sizes with well-performing tropical pines and eucalyptus in degraded lands. Native forest species such as the pino chuncho (Schizolobium amazonicum) have been identified, which can be used for the recovery of degraded lands, soil improvement and conservation, as well as revegetation and ornamentation, among other uses. Uses also include wood production, such as furniture, tongue-and-groove constructions, pulp 
and paper, drawers, as well as matchsticks and toothpicks. Furthermore, it is known for its melliferous and polliniferous value (PALOMINO: MARCIANO, 2003).

Plantation wood has been scarcely studied in Peru, which, according to Bustamante (2010), hinders the use of forest plantations in the Central Forest (Chanchamayo, Satipo, Oxapampa), Ucayali (Provinces of Padre Abad and Coronel Portillo), and Loreto (Maynas, Requena, Yurimaguas). The production system to be improved is studying secondary transformation processes or the workability of the wood. For this reason, the behavior of the wood was evaluated when exposed to planing, molding, drilling, and turning. The wood species evaluated were tornillo, pino chuncho, marupa, and capirona, all from forest plantations in the Ucayali Region.

According to Acevedo and Kikata (1994) and Gomes et.al. (2016), from a macroscopic viewpoint, pino chuncho wood has poorly differentiated growth rings, no grain, a surface that is smooth to the touch, of medium texture and with irregular interlocked grain. It has pores that are slightly visible to the naked eye (diffuse), solitary and scarce with 1 to 3 pores $/ \mathrm{mm}^{-2}$. It has a basic density of $0.36 \mathrm{~g} / \mathrm{cm}^{-3}$ and is recommended for use in nonstructural carpentry, covering, furniture, toys, model airplanes, drawers, formwork, particle board, and plywood.

When evaluating the susceptibility to attacks by xylophagous fungi of Schizolobiun amazonicum of pino chuncho wood at 17-year-old plantations in the Alexander Von Humboldt National Forest in Ucayali - Peru, Ramos et al. (2016) classified it as "non-resistant" due to its natural durability, a condition that shortens the useful life of the wood and negatively influences the potential use of the wood of this species, especially when the response of the wood to preservative treatment is unknown. In this regard, Araujo et al. (2012), when evaluating the durability of Eucalyptus citriodora (Corymbia citriodora) wood stakes treated with type-C chromated copper arsenate (CCA-C), observed that 60 months after the test, none of the samples had been attacked, and they were therefore found to have a minimum level of degradation.

According to Vignote (2006), the preservatives conveniently applied to the wood by different methods and concentrations make it resistant to attacks by fungi and insects, and can be simple chemical compounds or mixtures of organic or inorganic origin. Based on this information, Lebow (2010) indicates that, although several CCA formulations have been used in the past, type $\mathrm{C}$ has been the main formulation and is currently the only one considered in the standards of the American Wood Protection Association (AWPA). It is composed of $18.5 \%$ copper oxide (fungicide), 34\% arsenic pentoxide (insecticide), and $47.5 \%$ chromium trioxide (fixative); knowing the percentages of the formulation is seen as an advantage.

CCA-C is the type most commonly used because of its effectiveness, for being less toxic than other formulations and for its resistance to leaching, according to Peraza (2002) and Lebow (2010), stating that alkaline chromates reduce its corrosive effect; it is safe for indoor use and in the protection of wood in direct contact with soil and seawater. In that regard, Morrell (2004) notes that CCA-C treated poles were investigated near Gainesville, Florida; arsenic levels in the soil adjacent to the treated wood ranged from 1.74 to $8.19 \mathrm{ppm}$, decreasing to less than $1 \mathrm{ppm}$ at 150- and 300-mm distance regardless of the depth sampled. The results suggest that soil contamination by wood that has been treated with CCA-C for 45 years, is minimal.

The vacuum-pressure method allows for regulating the treatment conditions, by varying the penetration and retention of the preservative depending on the final use. Therefore, Lebow (2010) mentions that the parameters to be evaluated to determine the effectiveness of the preservative treatment are the amount of preservative absorbed by the wood (absorption), the amount of oxides retained in the wood after treatment (retention), and the depth of the preservative in the wood at the end of the process, forming a protective ring in the wood (penetration).

The vessels vary in size and distribution and are the conductors of the solution through the wood, free of any inclusion favoring the absorption and penetration of the preservative, depending on the permeability of the surrounding wood (PERAZA, 2002; VIGNOTE, 2006). Peraza (2002) also considers that fibers are not to be considered important factors in the initial penetration although they have influence in the subsequent extension of the liquids of the vessels, unlike the rays that, by the obstruction of protoplasm and extractives do not facilitate the penetration of preservatives. In this regard, Campos et al. (2003) and Lebow (2010) state that this is explained by the anatomical, physical and chemical alterations of the sapwood when it transforms into heartwood, by accumulating extractives that color it and reduce its permeability.

The density of dry wood at a moisture content (MC) less than or equal to $30 \%$, shows the amount of free spaces (cell cavities) to contain liquids according to Peraza (2002), stating that the greater these cavities are, the lower the density and the greater the absorption that the wood will achieve. Thus, drying the wood is of utmost importance in the preservation treatment. Lebow (2010) states that free water prevents the entry of the preservative liquid in most treatment methods; once the free water is eliminated, the wood is suitable to receive the preservative substances.

The objective of this research was to show that the immersion treatment of wood provides retention and penetration values of the CCA-C preservative for non-structural interior and exterior uses. Regardless of the treatment method, time is a determinant in the retention and penetration of CCA-C preservative in the wood. The increase in pressure during an equal time period of full-cell treatment is determinant in increasing the retention

FLORESTA, Curitiba, PR, v. 51, n. 3, p. 586-595, jul/set 2021. 
and penetration of the CCA-C preservative into the wood. Therefore, the aim of this study was to evaluate the quality of the treatment, by means of the retention and penetration of the water-soluble preservative CCA-C in pino chuncho wood (Schizolobium amazonicum Huber. Ex Ducke), for non-structural indoor $\left(4 \mathrm{~kg} / \mathrm{m}^{-3}\right)$ and outdoor $\left(6.4 \mathrm{~kg} / \mathrm{m}^{-3}\right)$ use, applying both the simple immersion and full-cell methods.

\section{MATERIAL \& METHODS}

\section{Sample Selection \& Collection.}

Five pino chuncho trees (Schizolobium amazonicum Huber ex Ducke) were selected based on the American Society for Testing and Materials - ASTM D-5536 (2004), in the 23-year old demonstration plantation of 1ha (400 plants/ha ${ }^{-1}$ ) of the Alexander Von Humboldt Experimental Station, located within the Alexander Von Humboldt National Forest, at $86 \mathrm{~km}$ from the city of Pucallpa, Peru, between $8^{\circ} 31^{\prime} 00-8^{\circ} 50^{\prime} 30$ South Latitude and $74^{\circ} 14^{\prime} 27-74^{\circ} 55^{\prime} 10$ West Longitude. From a political viewpoint, the plantation belongs to the Department of Ucayali, Province of Padre Abad and District of Irazola. It is located at 225 meters above sea level and registers an average temperature of $26.7^{\circ} \mathrm{C}$, an average relative humidity of $78.9 \%$ and an average annual rainfall of 3600 $\mathrm{mm}$. The area includes tropical humid forest and very humid tropical forest life zones.

From each tree, four logs with a length of $1.5 \mathrm{~m}$ each were obtained, which were sawn into planks from which wood specimens were obtained with a $50 \times 50 \mathrm{~mm}$ cross section, $500 \mathrm{~mm}$ in length, free of defects in shape, structure, knots and biological attacks, in accordance with the Peruvian Technical Standard - NTP 251.008 (2012). Given the characteristics of the lower-permeability heartwood (VIGNOTE, 2006; CAMPOS, 2003), which is characterized by its poorly differentiated pale-brown color and equal susceptibility to biological attacks as the sapwood (RAMOS et al., 2016), 64 heartwood specimens were selected (Table 1) in order to obtain information that allows for effective application of the results in both the sapwood and the heartwood (LEBOW, 2010; PERAZA, 2002). The specimens were dried to a $15 \%$ moisture content in order to control their influence on the variation of the retention values achieved by the treatments used (AMARAL, et al., 2014).

Table 1: Number of Samples and Characteristics of the Simple Immersion and Full-cell Treatments Tabela 1: Número de testes e características de tratamentos de imersão simples e célula cheia

\begin{tabular}{|c|c|c|c|c|c|}
\hline \multicolumn{2}{|c|}{ Simple Immersion } & \multicolumn{4}{|c|}{ Full cell } \\
\hline Days & $\begin{array}{c}\text { Sample } \\
\text { No. }\end{array}$ & $\begin{array}{l}\text { Load } \\
\text { No. }\end{array}$ & $\begin{array}{c}\text { Sample } \\
\text { No. }\end{array}$ & $\begin{array}{l}\text { Pressure } \\
\left(\text { lb./in. }{ }^{-2}\right)\end{array}$ & $\begin{array}{l}\text { Pressure Period } \\
\text { (Minutes) }\end{array}$ \\
\hline 2 & 4 & 1 & 4 & 120 & \\
\hline 4 & 4 & 2 & 4 & 150 & 10 \\
\hline 6 & 4 & 3 & 4 & 180 & \\
\hline 8 & 4 & 4 & 4 & 120 & \\
\hline 10 & 4 & 5 & 4 & 150 & 20 \\
\hline 12 & 4 & 6 & 4 & 180 & \\
\hline 14 & 4 & 7 & 4 & 120 & \\
\hline-- & - & 8 & 4 & 150 & 30 \\
\hline-- & - & 9 & 4 & 180 & \\
\hline
\end{tabular}

\section{Treatment Methods, Evaluation of the Quality of Treated Wood \& Statistical Analysis.}

ARSENAL NFB 72 ® - CCA-C preservative with a 72\% oxide factor was used, in accordance with NTP 251.060 (2012) and AWPA P23-14 (2016). The total Solids Concentration (TSC) $=4.0 \%$ of the preservative corresponds to $2.88 \%$ total oxides concentration (PERAZA, 2002; LEBOW, 2010). To achieve the minimum CCA-C preservative retentions for non-structural indoor and outdoor use (covering) of 4 and $6.4 \mathrm{~kg} / \mathrm{m}^{-3}$ respectively, the simple-immersion method was used in the period from 2 to 14 days with evaluations performed every other day (Table 1), and the full-cell method (Bethell), with an initial vacuum period of $15 \mathrm{~min}$ at 10.1 lb./in..$^{-2}$, treatment pressures of 120, 150, and $180 \mathrm{lb} . / \mathrm{in}^{-2}$ at pressure periods of 10,20 and 30 min each (Table 1) and a final vacuum period of $10.1 \mathrm{lb} . / \mathrm{in} .^{-2}$ for 15 minutes, considering the indications of NTP 251.019 (2016) for the immersion treatment and NTP 251.034 (2012) for the full-cell method.

The quality of the wood treatment was assessed based on NTP 251.026 (2017), and the treatment was characterized based on the penetration of the preservative after six weeks of airing (KOSE; KARTAL, 2010), through a cross section in half the length of the specimens, where the reagent chrome azurol was applied, so that after 24 hours a violet blue color was observed, resulting from the reaction. The absorption was determined with the mass of the specimens before and after the treatment. This procedure was used for both the simple-immersion method and the full-cell method. The retention was calculated with the absorption value and the concentration of CCA-C oxides used. The calculations were made using equations 1 and 2 below (PEREZA, 2002): 


$$
A=\frac{(f w-m o)}{V}
$$

$$
\mathbf{R}=\frac{(f w-m o) \% T S C * O . F}{V 100}
$$

Where: $\mathbf{A}=$ Absorption $\left(\mathrm{kg} / \mathrm{m}^{-3}\right), \mathbf{R}=$ Retention $\left(\mathrm{kg} / \mathrm{m}^{-3}\right), \mathbf{O . F} .=$ Oxidation factor, $\mathbf{f}_{\mathbf{w}}=$ Final weight of the test specimen after treatment $(\mathrm{kg}), \mathbf{m}_{0}=$ Initial weight of the test specimen before treatment $(\mathrm{kg}), \mathbf{V}$ $=$ Test specimen volume $\left(\mathrm{m}^{3}\right) ;$ and TSC $=$ Total Solids Concentration in the preservative product $(\%)$.

For the statistical evaluation of the results and application of the Analysis of Variance (ANOVA), compliance with the normal distribution of the retention values was previously verified using the AndersonDarling test, and the constancy of the error variance with the Bartlett's test. For the simple immersion results, the Completely Randomized statistical Design (CRD) was used, with an equal number of replicates, performing the comparison test by the Fisher Least Significant Difference (LSD) method ( $p<0.05$ ), for the significant factors by the F test $(\mathrm{p}<0.05)$ of the ANOVA, the variable being the days of immersion. For the vacuum-pressure results, the factorial analysis design of experiments $(3 \times 2)$ was used. The variables were pressure level (three pressures), time period (three times), and the degree of interaction between these two variables.

\section{RESULTS}

\section{CCA-C Penetration, Absorption \& Retention using the Simple Immersion and Full-cell Methods.}

In Figure 1, the specimens indicated as A, B and C treated by simple immersion for 2, 6 and 14 days, respectively, show partial vascular type preservative penetration. Likewise, specimens 1,2 and 3 treated by the full-cell method with $120 \mathrm{lb} . /$ in. $^{-2}$ for 10,20 and 30 minutes, respectively, show a penetration of the partial vascular type preservative, while specimens 1, 4 and 5 treated for 10 minutes with 120, 150 and $180 \mathrm{lb} . /$ in. $^{-2}$ respectively, showed partial vascular, irregular partial and regular total preservative penetrations, respectively.

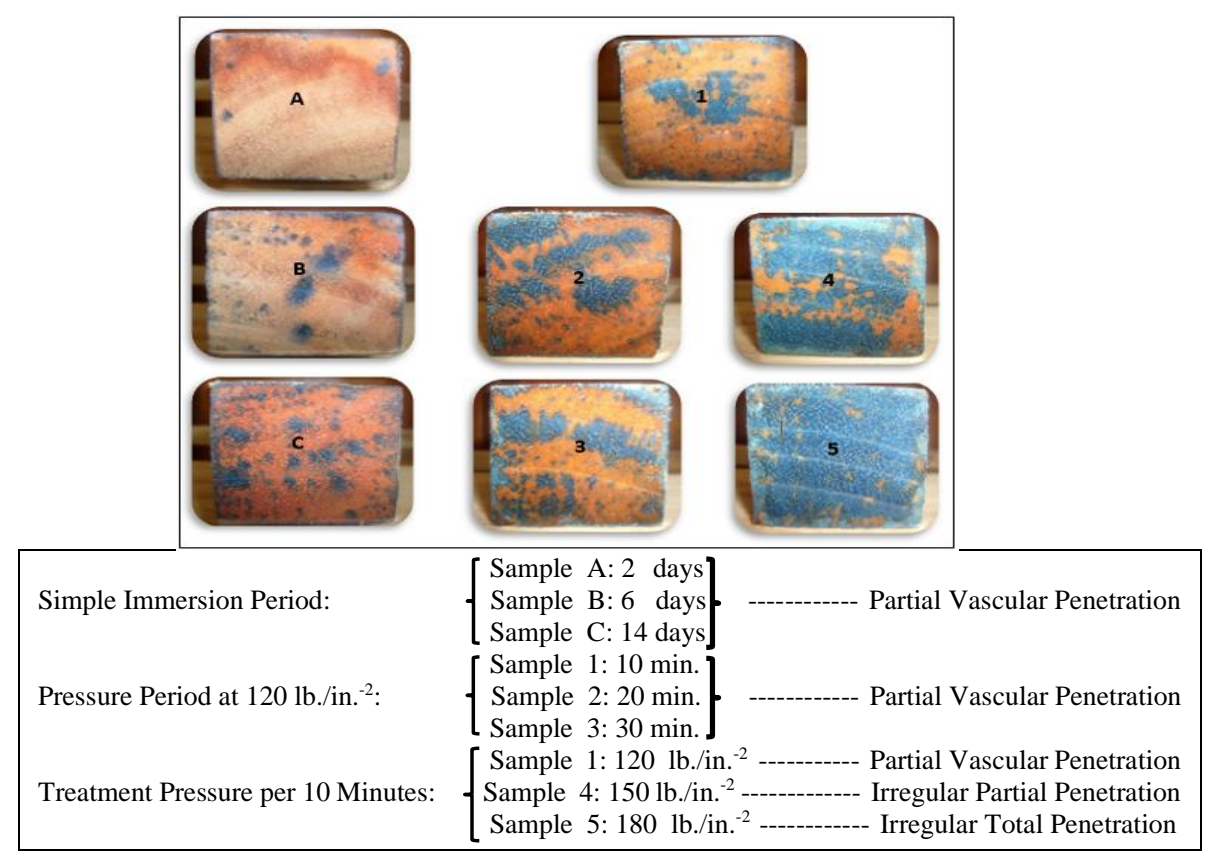

Figure 1: Variation of CCA-C Penetration in pino chuncho wood using the simple immersion and full-cell methods.

Figura 1: Variação da penetração de CCA em madeira de pinho chuncho por métodos de simples imersão e célula cheia

Figure 2 shows the logarithmic trend curve of the increase in CCA-C preservative retentions in pino chuncho wood using the simple immersion method, during the time period from 2 to 14 days, with a maximum average retention of $3.66 \mathrm{~kg} / \mathrm{m}^{-3}$, without reaching the minimum retentions for non-structural indoor and outdoor use. 


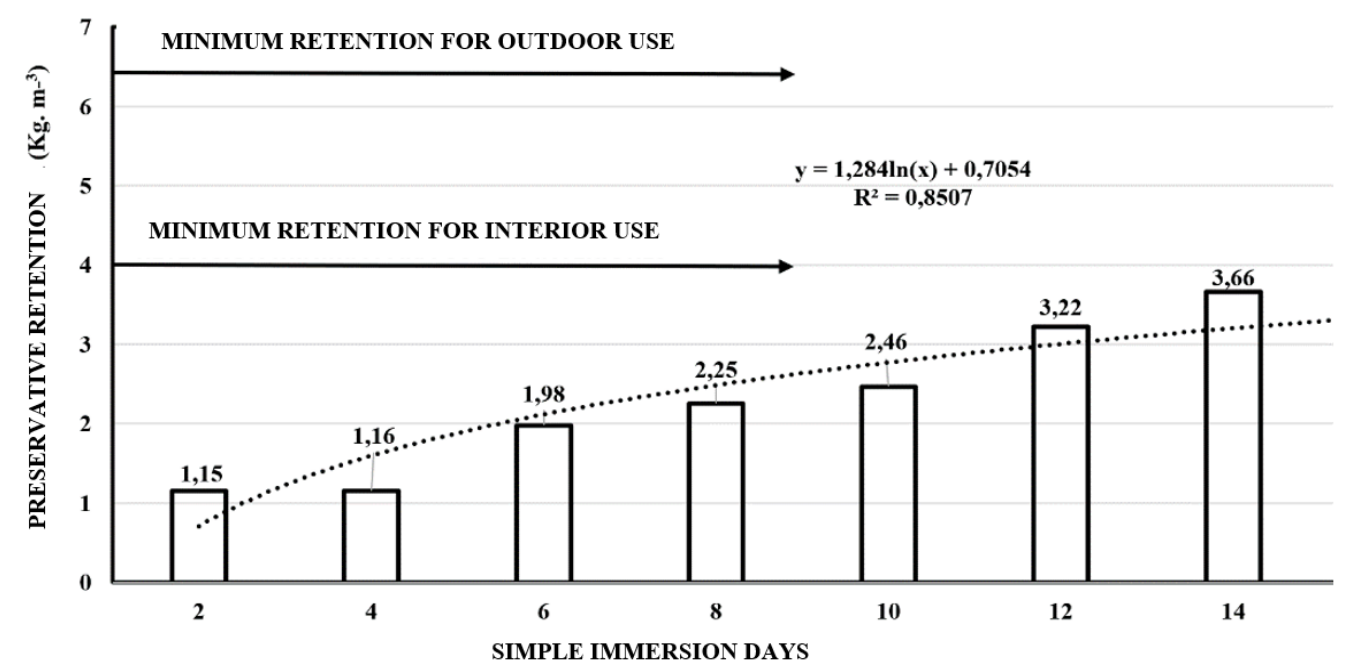

Figure 2: Logarithmic trend curve of the average retention values of CCA-C in pino chuncho wood using the simple immersion method

Figura 2: Curva de tendência logarítmica dos valores médios de retenção de CCA-C em madeira de pinho chuncho utilizando o método de imersão simples

Figure 3 shows the polynomial trend curves of the increase in CCA-C preservative retention in pino chuncho wood treated by the full-cell method. As can be observed, with a pressure of $120 \mathrm{lb} . / \mathrm{in} .^{-2}$ and time periods of 10,20 and 30 minutes, average retentions of $3.2,3.6$ and $3.9 \mathrm{~kg} / \mathrm{m}^{-3}$ respectively, were reached. With $150 \mathrm{lb}^{-/ i n}$. $^{-}$ 2 and 10, 20 and 30 minutes of treatment, average retentions of $5.1 ; 5.5$ and $5.9 \mathrm{~kg} / \mathrm{m}^{-3}$ were observed, respectively, and with $180 \mathrm{lb} . / \mathrm{in} .^{-2}$ at 10,20 and 30 minutes, average retentions of $5.6,7.4$ and $8.1 \mathrm{~kg} / \mathrm{m}^{-3}$ were obtained, respectively.

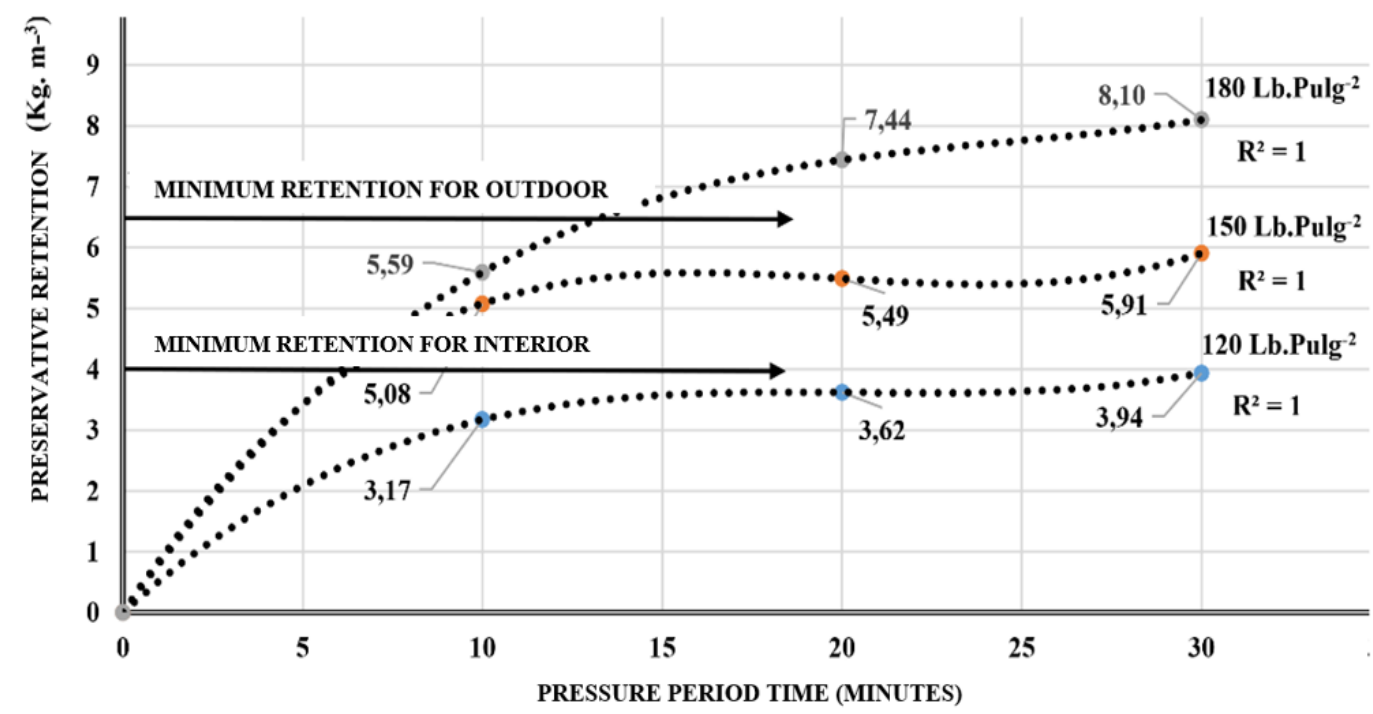

Figure 3: Polynomial trend curves of average CCA-C retention values in pino chuncho wood using the full-cell method.

Figura 3: Curvas de tendência polinomial de valores médios de retenção CCA-C em chuncho de pinho utilizando o método de célula cheia.

Table 2 shows the preservation characteristics of pino chuncho wood using the simple immersion method, where the absorption and retention of the preservative increase with the treatment time, without changing the type of partial vascular penetration observed. At the 5\% significance level, the p-value for the Anderson-Darling test was $0.213(p<\alpha)$, confirming normal distribution of the sample. As for homogeneity of variances, the p-value for the Bartlett's test was $0.525(\mathrm{p}>\alpha)$. 
Table 2: CCA-C Absorption, Retention and Penetration in pino chuncho wood using the simple immersion method

Tabela 2: Absorção, retenção e penetração de CCA-C em madeira de pinho chuncho utilizando o método de imersão simples

\begin{tabular}{cccc}
\hline $\begin{array}{c}\text { Immersion } \\
(\text { Days })\end{array}$ & $\begin{array}{c}\text { Absorption } \\
\left(\mathrm{kg} / \mathrm{m}^{-3}\right)\end{array}$ & $\begin{array}{c}\text { Retention } \\
\left(\mathrm{kg} / \mathrm{m}^{-3}\right)\end{array}$ & Penetration \\
\hline 2 & 39.98 & 1.15 & Partial Vascular \\
4 & 40.12 & 1.16 & Partial Vascular \\
6 & 68.68 & 1.98 & Partial Vascular \\
8 & 78.24 & 2.25 & Partial Vascular \\
10 & 85.56 & 2.46 & Partial Vascular \\
12 & 111.90 & 3.22 & Partial Vascular \\
14 & 127.04 & 3.66 & Partial Vascular \\
\hline
\end{tabular}

Table 3 shows the preservation characteristics of pino chuncho wood using the full-cell method. It can be observed that the absorption and retention of the preservative increase with the treatment time, without changing the type of penetration observed at each treatment pressure. Likewise, the higher the pressure at the same treatment time, the higher the average retention and penetration of the preservative in the wood. In the normal distribution test of the averages of retention values at the 5\% significance level, the p-value for the Anderson-Darling test was found to be $0.468(\mathrm{p}<\alpha)$, which conforms the normal distribution of the sample. As for the homogeneity of variances, the $p$-value for the Bartlett's test was $0.259(p>\alpha)$.

Table 3: CCA-C Absorption, Retention and Penetration in pino chuncho wood in pressure values and variable periods using the full-cell method

Tabela 3: Absorção, retenção e penetração de CCA-C em madeira de pinho chuncho em valores de pressão e períodos variáveis utilizando o método de célula cheia

\begin{tabular}{ccccc}
\hline $\begin{array}{c}\text { Pressure } \\
\left(\text { lb./in. }^{-2}\right)\end{array}$ & $\begin{array}{c}\text { Period } \\
(\text { Minutes })\end{array}$ & $\begin{array}{c}\text { Absorption } \\
\left(\mathrm{kg} / \mathrm{m}^{-3}\right)\end{array}$ & $\begin{array}{c}\text { Retention } \\
\left(\mathrm{kg} / \mathrm{m}^{-3}\right)\end{array}$ & $\begin{array}{c}\text { Average } \\
\text { Penetration }\end{array}$ \\
\hline \multirow{2}{*}{120} & 10 & 110.2 & 3.17 & Partial Vascular \\
& 20 & 125.5 & 3.62 & Partial Irregular \\
\hline \multirow{2}{*}{150} & 30 & 136.7 & 3.94 & 5.08 \\
& 10 & 176.3 & 5.49 & Regular Total \\
\hline
\end{tabular}

Table 4 shows the analysis of variance (ANOVA) of the CCA-C retention averages in pino chuncho wood treated by simple immersion, with significant differences between the average retention values at a significance level of 5\%. This table also shows the ANOVA of the CCA-C retention averages in pino chuncho wood treated by the full-cell method, with significant differences between the average retention values due to the effect of the treatment pressure level at the 5\% significance level.

Table 4: Analysis of variance of the retention averages of CCA-C in pino chuncho wood using the simple immersion and full-cell methods

Tabela 4: Análise de variância das médias de retenção de CCA-C em madeira de pinus chuncho por simples imersão e célula cheia 


\begin{tabular}{|c|c|c|c|c|c|}
\hline Variation Source & Degrees of Freedom & Sum of Squares & Mean Squares & $\mathrm{F}$ & $\mathrm{p}$ \\
\hline \multicolumn{6}{|c|}{ Simple Immersion } \\
\hline Days & 6 & 21.812 & 3.6353 & 24.34 & 0,000 \\
\hline Error & 21 & 3.136 & 0.1493 & & \\
\hline Total & 27 & 24.948 & & & \\
\hline \multicolumn{6}{|l|}{ Full Cell } \\
\hline Pressure & 2 & 72.399 & 36.199 & 7.61 & 0,002 \\
\hline Period & 2 & 11.562 & 5.781 & 1.22 & 0,312 \\
\hline$\overline{\text { Period }} *$ Pressure & 4 & 4.475 & 1.119 & 0.24 & 0,916 \\
\hline Error & 27 & 128.384 & 4.755 & & \\
\hline Total & 35 & 216.820 & & & \\
\hline
\end{tabular}

Table 5 shows the comparison of the CCA-C retention averages in pino chuncho wood treated by simple immersion. Fisher's LSD method shows that retention values on day 12 and 14 were significantly higher at the 5\% significance level. The comparison of means of CCA-C retention using the full-cell method is also shown. Fisher's LSD method shows that retention values at $180 \mathrm{lb} . / \mathrm{in} .{ }^{-2}$ for 20 and 30 minutes were significantly higher than the retention values achieved with $120 \mathrm{lb} . / \mathrm{in} .^{-2}$ at all three time levels at the $5 \%$ significance level.

Table 5: Comparison of CCA-C retention averages in pino chuncho wood using the simple immersion and fullcell methods

Tabela 5: Comparação das médias de retenção de CCA-C em madeira de pinus chuncho utilizando os métodos de simples imersão e célula cheia

\begin{tabular}{|c|c|c|c|c|c|}
\hline \multicolumn{6}{|c|}{ Simple Immersion Method } \\
\hline Days & & $\mathrm{N}$ & Average & Gro & \\
\hline 14 & & 4 & 3.659 & A & \\
\hline 12 & & 4 & 3.223 & $\mathrm{~A}$ & \\
\hline 10 & & 4 & 2.464 & \multicolumn{2}{|c|}{ B } \\
\hline 8 & & 4 & 2.253 & \multicolumn{2}{|c|}{ B } \\
\hline 6 & & 4 & 1.978 & \multicolumn{2}{|c|}{$\mathrm{B}$} \\
\hline 4 & & 4 & 1.155 & & $\mathrm{C}$ \\
\hline$\underline{2}$ & & 4 & 1.151 & & $\mathrm{C}$ \\
\hline \multicolumn{6}{|c|}{ Full-Cell Method } \\
\hline Pressure & Period & $\mathrm{N}$ & Average & \multicolumn{2}{|c|}{ Group * } \\
\hline 180 & 30 & 4 & 8.096 & A & \\
\hline 180 & 20 & 4 & 7.439 & A & \\
\hline 150 & 30 & 4 & 5.905 & $\mathrm{~A}$ & B \\
\hline 180 & 10 & 4 & 5.591 & A & B \\
\hline 150 & 20 & 4 & 5.490 & A & $\mathrm{B}$ \\
\hline 150 & 10 & 4 & 5.077 & A & B \\
\hline 120 & 30 & 4 & 3.936 & & B \\
\hline 120 & 20 & 4 & 3.615 & & B \\
\hline 120 & 10 & 4 & 3.173 & & B \\
\hline
\end{tabular}

* Measurements that do not share a letter are significantly different (Fisher's LSD Method, $\mathrm{p}<0.05$ )

\section{DISCUSSION}

\section{CCA-C Penetration - Simple Immersion \& Full-Cell Methods}

The partial vascular type penetration of specimens A, B, and C with different days of treatment (Figure 1), was the penetration found in the pino chuncho wood in the seven simple immersion treatments (Table 2), observing a limited influence of the treatment time on the penetration of the preservative in the wood. According to Peraza (2002) and Vignote (2006), this lack of distribution of the preservative in the other anatomical elements depends on the permeability of the surrounding wood that surrounds the vessels. This disqualifies the simple immersion method for the treatment of pino chuncho wood for indoor and outdoor non-structural use, as it does not form a preservative ring in the wood (LEBOW, 2010).

The partial vascular type penetrations shown in specimens 1,2 and 3 correspond to the full-cell treatment with $120 \mathrm{lb} . /$ in. $^{-2}$ for 10, 20 and 30 minutes respectively (Figure 1). The same reaction was observed with the irregular partial penetrations with $150 \mathrm{lb} . / \mathrm{in}^{-2}$ and regular full penetration with $180 \mathrm{lb} . / \mathrm{in} .^{-2}$. The type of penetration 
did not vary with increasing treatment time. In this regard, Tripathi and Kumar (2015) consider that factors such as the presence of small or solitary and few pores were the reasons for the difficulty of treatment of heartwood of Melia composita of basic density $0.45 \mathrm{~g} \mathrm{~cm}^{3}$, by the full-cell method with CCA at $4 \%$ industrial concentration and $150 \mathrm{lb} . / \mathrm{in}^{-2}$ of pressure for one hour, reaching a partial vascular penetration (15\% of the cross-sectional area, on average).

The use of higher treatment pressure values influenced the variation of the average penetration type in the three pressure period times (Table 3). In Figure 1, specimens 1, 4 and 5 show that at higher treatment pressure, CCA-C penetration is higher. In this regard, Lebow (2010) points out that the degree of heartwood impermeability is the difficulty due to which the preservative does not penetrate the wood, and this is explained by the anatomical, physical and chemical alterations that occur during its transformation. Thus, to treat fence posts of Eucalyptus urophylla from a 5-and-a-half-year-old plantation, with basic density of $0.47 \mathrm{~g} / \mathrm{cm}^{3}$ and humidity less than $30 \%$, Valle et al. (2013) the full-cell method was used, with CCA-C at $2 \%$ of active ingredients and with $180 \mathrm{lb} . / \mathrm{in} .{ }^{-2}$ for 1.5 hours, achieving full penetration of the sapwood but not the heartwood. Pino chuncho with a basic density of $0.36 \mathrm{~g} \mathrm{~cm}^{-3}$ according to Acevedo and Kikata (1994) has solitary and scarce pores that are slightly visible to the naked eye (diffuse), with 1 to 3 pores. $\mathrm{mm}^{-2}$, which would explain the partial vascular and partial irregular penetrations observed.

\section{CCA-C Retention - Simple Immersion \& Full-cell Methods}

ANOVA at the 5\% significance level of the CCA-C retention averages of the seven simple immersion treatments performed, determined a $p$ value for the F test of $0.000(p<\alpha)$, conforming Fisher's LSD method detecting significant differences between the highest retention values achieved at days 12 and 14 and the lowest retention values of the shorter duration treatments (Table 4). The lowest CCA-C retention values were significantly lower in the treatments carried out on day two and four. These results are due to the anatomical characteristics of each wood species, such as the density and permeability of the wood to be treated (ALFARO, 2013), as well as factors related to the process conditions that influence the penetration of liquids into the wood, such as pressure, temperature and time, the latter being an important factor in methods where no pressure is applied (WOTTIZ 2009).

Based on the ANOVA values of the CCA-C average retention values resulting from the factors pressure level (three pressures), time period (three times), and the degree of interaction between these two variables (Table 4 ), it was determined that time and pressure-time interaction did not influence retention levels in a determinant manner, as the $p$ values for the $F$ test were 0.312 and 0.916 respectively $(p<\alpha)$. Unlike the treatment pressure factor with a $p$ value for the $F$ test of $0.002(p>\alpha)$, it is concluded that at least one level of treatment pressure significantly influenced CCA-C retention levels at the 5\% significance level.

The comparison of CCA-C average retention values resulting from treatment pressures at varying time periods using the Fisher's LSD method (Table 5), shows that the CCA-C retention values of the treatment with $180 \mathrm{lb} . / \mathrm{in}^{-2}$ applied for 20 and 30 minutes were significantly higher than the retention values achieved with 120 lb./in. ${ }^{-2}$ at all three application time levels, turning it effective even for woods that are in contact with the soil (ARAUJO et al., 2012; LEBOW, 2010).

\section{Minimum Retentions for Non-structural Indoor and Outdoor Use}

The logarithmic trend curve of average CCA-C retention values in pino chuncho wood using the simple immersion method (Figure 2), reached its maximum value of $3.66 \mathrm{~kg} / \mathrm{m}^{-3}$ on day 14 , not reaching the minimum retention for indoor nonstructural use of $4 \mathrm{~kg} / \mathrm{m}^{-3}$ and outdoor of $6.4 \mathrm{~kg} / \mathrm{m}^{-3}$ (AWPA P23-14, 2016). The minimum retentions recommended by standard, according to Lebow (2010), are determined by the conditions of use of the wood and the type of preservative; the minimum retentions are the values required for the preservation of the wood against the effect of destructive agents present at the location where it will be implemented, which means such values must be reached together with the penetration ring of the preservative.

The polynomial trend curves of the average CCA-C retention values of pino chuncho wood treated with the full-cell method (Figure 3) show that treatment of the wood with pressure of $120 \mathrm{lb} . / \mathrm{in}^{-2}$ at treatment times of 10, 20 and 30 minutes, does not achieve the minimum retentions for the proposed use, in addition to presenting a vascular type penetration. With $150 \mathrm{lb} . /$ in. $^{-2}$ and 10, 20 and 30 minutes of treatment, the average retentions were $5.1,5.5$ and $5.9 \mathrm{~kg} / \mathrm{m}^{-3}$ respectively, although they are adequate for non-structural indoor uses, but when presenting irregular partial penetrations of the preservative, it is not recommended for the treatment of pino chuncho wood. According to Wottiz (2009), the improvement of the preservation characteristics of pino chuncho is explained to a greater extent by the pressure factor and to a lesser extent by the time factor, which have an additive influence on the retention and penetration of the preservative.

Finally, the treatment of wood with $180 \mathrm{lb} . /$ in. $^{-2}$, which with 10 minutes of treatment allowed for reaching average retentions of $5.6 \mathrm{~kg} / \mathrm{m}^{-3}$ suitable for indoor non-structural use; and with 20 and 30 minutes of treatment reached average retentions of 7.44 and $8.1 \mathrm{~kg} / \mathrm{m}^{-3}$, suitable for indoor and outdoor non-structural use, showing in

FLORESTA, Curitiba, PR, v. 51, n. 3, p. 586-595, jul/set 2021. 
all three cases regular total penetrations. In this regard, Terezo et al. (2017) evaluated the susceptibility to termite attacks of sapwood and heartwood of pino chuncho (Schizolobium parahyba var. Amazonicum), contrasting untreated wood and wood treated with CCA-C at a $1.8 \%$ concentration, using the full-cell method with a pressure of $120 \mathrm{lb} . / \mathrm{in}^{-2}$. Determining that in this condition it was resistant to attacks by Cryptotermes brevis (Walker) termites, inducing a high mortality of $75.6 \%$ and no perforations.

\section{CONCLUSIONS}

- The retention and penetration values of CCA-C preservative in pino chuncho wood (Schizolobium amazonicum), required for non-structural indoor and outdoor use, were not achieved by the simple immersion method.

- The retention and penetration values of CCA-C preservative in pino chuncho wood (Schizolobium amazonicum) required for non-structural indoor and outdoor use were achieved by the full-cell method with treatment pressures of $180 \mathrm{lb} . / \mathrm{in}^{-2}$ and pressure periods of 20 and 30 minutes.

- The CCA-C preservative retention values in pino chuncho wood (Schizolobium amazonicum), required for non-structural indoor use, were achieved by the full-cell method with treatment pressures of $180 \mathrm{lb} . / \mathrm{in} .{ }^{-2}$ and 10-minute pressure periods, and $150 \mathrm{lb} . / \mathrm{in}^{-2}$ with pressure periods of 10, 20 and 30 minutes.

- The retention and penetration values of CCA preservative in pino chuncho wood (Schizolobium amazonicum) required for non-structural indoor and outdoor use were not achieved by the full-cell method with treatment pressures of $120 \mathrm{lb} . /$ in. $^{-2}$ for none of the pressure periods tested.

- The increase in pressure at an equal treatment time period was decisive in the increase in retention from one pressure level to a higher one. However, the increase in the time period of treatment pressure application was not significant in the increase in retention from one time period to another higher time period.

\section{REFERENCES}

ACEVEDO, M.; KIKATA, Y. Atlas de maderas del Perú. Publifor, Lima, 1994.

ALFARO, P. J. D. Estudio de retención y penetración de tres preservantes comerciales en nueve especies maderables presentes en Costa Rica. Ingeniería, Turrialba, v. 23, n. 1, p. 107 - 119, jan./july. 2013.

AMARAL, L. S.; MOREIRA, S. J. R.; GHERARDI, H. P. R.; TRUGILHO, P. F. Influência do diâmetro e umidade no tratamento preservativo de moirões de Eucalyptus. Revista Árvore, Viçosa v.38, n.5, p. 919-925, aug. 2014.

ARAUJO, H. J. B.; MAGALHÃES, W. L. E.; OLIVEIRA, L. C. Durabilidade de madera de eucalipto citriodora (Corymbia citriodora (Hook.) K.D. Hill \& L.A.S. Johnson) tratada com CCA-C em ambiente amazônico. Acta Amazonica, Manaus, v. 42, n. 1, p. 49-58, mar. 2012.

AMERICAN SOCIETY FOR TESTING AND MATERIALS. ASTM D 5536-94. Standard practice for sampling forest trees for determination of clear word properties. Annual Book of ASTM Standards, West Conshohocken, 2004.

AMERICAN WOOD PROTECTION ASSOCIATION. AWPA P23-14: Standard for Chromated Copper Arsenate Type C (CCA-C). AWPA Book of Standards, Birmingham, 2016.

BUSTAMANTE, G. N. Estudio de trabajabilidad de la madera de cuatro especies procedentes de plantaciones en la región Ucayali. Sub proyecto "Opciones para la promoción e Innovación Tecnológica de Maderas Procedentes de Plantaciones Forestales con Especies Nativas de la Región Amazónica”, Lima, 2010.

CAMPOS, C.; FRASCO, B. E.; DE MENDOZA, M. Estudo da variabilidade da retenção do preservante CCA tipo A na madeira de Brosimum rubescens Taub. Moraceae - (pau-rainha) uma espécie madeireira da região amazónica. Revista Árvore, Viçosa, v.27, n.6, p. 845-853, nov./dez. 2003.

GOMES, S. M.; AKIRA, M. F.; COSTA, F. G.; OLIVEIRA, R. A.; GUIMARAES, C. A.; CAMPOS, B. A. Estudo anatomico e físico da madeira de Schizolobium parahyba var. Amazonicum proveniente de povoamentos nativos da Amazonia Oriental. Sciencia Forestal, Piracicaba, v. 44, n. 110, p. 293-301, jun. 2016

KOSE, C.; KARTAL, S.N. Tolerance of brown-rot and dry-rot fungi to CCA and ACQ wood preservatives. Tubitak. Turkish Journal of Agriculture Forestry., v 34, n. 3, p. 181 - 190, jun. 2010.

LEBOW, S. T. Wood preservation. In: Wood handbook: wood as an engineering material. 100. ed. Madison: U.S. Department of Agriculture, Forest Service, Forest Products Laboratory. 2010, Chapter 15, p 1-28. 
MORRELL, J. J.; HUFFMAN, J. Copper, chromium, and arsenic levels in soils surrounding posts treated with chromated copper arsenate (CCA). Wood and Fiber Science, New York, v. 36, n. 1, p. 119-128, january 2004.

NORMAS TECNICAS PERUANAS. NTP 251.008. Maderas. Selección y colección de muestras. Lima, 2012.

NORMAS TECNICAS PERUANAS. NTP 251.019 Madera y carpintería para construcción. Preservación de maderas. Tratamientos preservadores. Definiciones y clasificación. Lima, 2016.

NORMAS TECNICAS PERUANAS. NTP 251.026: Preservación de madera. Penetración y retención de los preservadores en la madera. Lima, 2017.

NORMAS TECNICAS PERUANAS NTP 251.034: Preservación de madera. Preservación de postes de madera. Métodos a presión. Lima, 2017.

NORMAS TECNICAS PERUANAS. NTP 251.060: Preservación de madera. Preservadores cobre-cromoarsénico (CCA). Clasificación y requisitos. Lima, 2017.

PALOMINO, Y. J.; MARCIANO, B. C. Especies forestales nativas con potencial para reforestación en la provincia de Oxapampa y fichas técnicas de las especies de mayor prioridad. Programa Selva Central Oxapampa. Oxapampa, 2003.

PERAZA, S. F. Protección preventiva de la madera. Asociación de Investigación Técnica de las Industrias de la Madera y Corcho (AITIM). Madrid, 2002.

RAMOS, L. H.; TRUJILLO, C. F., GUZMAN, L. D. Y ARAUJO, F. M. Durabilidad natural de la madera de pino chuncho (Shizolobium amazonicum Huber. ex Ducke) a la acción de dos hongos de pudrición. Revista Forestal del Perú, Lima, v.3, n, 2, p. 81-89, julio / dic. 2016.

TEREZO, R. F.; CARBALLEIRA, L. G.; PAIVA, S. C.; BOURSCHEID, C. Resistência da madeira tratada de paricá (Schizolobium parahyba var. amazonicum (Huber ex. Ducke) Barneby) ao ataque de cupins. Ciência da Madeira, Pelotas, v. 8, n.3, p.187-193, nov. 2017.

TRIPATHI, S.; KUMAR, P. P. Treatability of Melia composita using vacuum pressure impregnation. Maderas. Ciencia y Tecnología, Concepción, v. 17, n. 2, p. 373 - 384, aug. 2015.

VALLE, M. L. A.; CASTRO, S. J.; MARIUS, D. L. R.; VIANA, E. W. Retenção e penetração de CCA em madeira de primeira e segunda rotação de Eucalyptus urophylla S.T. Blake. Ciencia Florestal, Santa María, v. 23, n. 2, p. $481-490$, abr./jun. 2013.

VIGNOTE, P. S.; MARTÍNEZ, R. I. Tecnología de la madera. 3. Ediciones Mundi-Prensa. Madrid, 2006.

WOTTIZ, C. A. Análisis teórico de las variables que influyen en la impregnación con preservantes hidrosolubles de tablas de dimensiones comerciales. Revista de Ciencias Forestales - Quebracho, Santiago del Estero, v. 17, n.1,2, p. $5-15$, dic. 2009. 